\title{
Organic carbon sources and sinks in San Francisco Bay: variability induced by river flow
}

\author{
Alan D. Jassby ${ }^{1}$, James E. Cloern ${ }^{2}$, Thomas M. Powell ${ }^{1,2}$ \\ ${ }^{1}$ Division of Environmental Studies, University of California, Davis, California 95616, USA \\ ${ }^{2}$ U.S. Geological Survey, 345 Middlefield Road MS-496, Menlo Park, California 94025, USA
}

\begin{abstract}
Sources and sinks of organic carbon for San Francisco Bay (California, USA) were estimated for 1980. Sources for the southern reach were dominated by phytoplankton and benthic microalgal production. River loading of organic matter was an additional important factor in the northern reach. Tidal marsh export and point sources played a secondary role. Autochthonous production in San Francisco Bay appears to be less than the mean for temperate-zone estuaries, primarily because turbidity limits microalgal production and the development of seagrass beds. Exchange between the Bay and Pacific Ocean plays an unknown but potentially important role in the organic carbon balance. Interannual variability in the organic carbon supply was assessed for Suisun Bay, a northern reach subembayment that provides habitat for important fish species (delta smelt Hypomesus transpacificus and larval striped bass Morone saxatilus). The total supply fluctuated by an order of magnitude; depending on the year, either autochthonous sources (phytoplankton production) or allochthonous sources (riverine loading) could be dominant. The primary cause of the year-to-year change was variability of freshwater inflows from the Sacramento and San Joaquin rivers, and its magnitude was much larger than long-term changes arising from marsh destruction and point source decreases. Although interannual variability of the total organic carbon supply could not be assessed for the southern reach, year-to-year changes in phytoplankton production were much smaller than in Suisun Bay, reflecting a relative lack of river influence.
\end{abstract}

\section{INTRODUCTION}

The sources of food and energy for estuarine food webs are diverse compared to those of other ecosystems. The diversity arises from several features, including the existence of an intertidal habitat, the supply of materials from rivers, and the waste products of contiguous human communities. In San Francisco Bay (SFB), dramatic changes during the 1970s and 1980s in species composition at higher trophic levels, including fishes and benthic invertebrates (Herbold et al. 1992), have resulted in a strong need for the delineation of food sources. Because San Francisco Bay has been a focus of investigation for over 2 decades (Conomos 1979a, Cloern \& Nichols 1985), much relevant information exists. It has never been integrated, however, into an assessment of the total organic matter supply, the relative importance of the different components, and the manner in which the supply is affected by both human activities and natural processes.
Our primary objective here is to synthesize information from a variety of places in order to identify and rank the important sources of organic carbon for the estuary, i.e. to assess the component parts comprising the system metabolism of SFB. Particular attention is paid to the influence of bathymetry on different flux estimates. Organic carbon sinks are also summarized, although the available data are much less comprehensive.

A second objective is based on the recognition that all terms composing an annual carbon budget are dynamic, i.e. they exhibit variability in space and time. We illustrate the variability in space by considering separately the southern and northern reaches of SFB (Fig. 1). Previous work has depicted marked differences for certain materials and processes in the 2 reaches. The southern reach, for example, is only weakly influenced by the Sacramento-San Joaquin Rivers, except during periods of very high river flow (Cloern 1991). In contrast, the northern reach is strongly influenced by river 


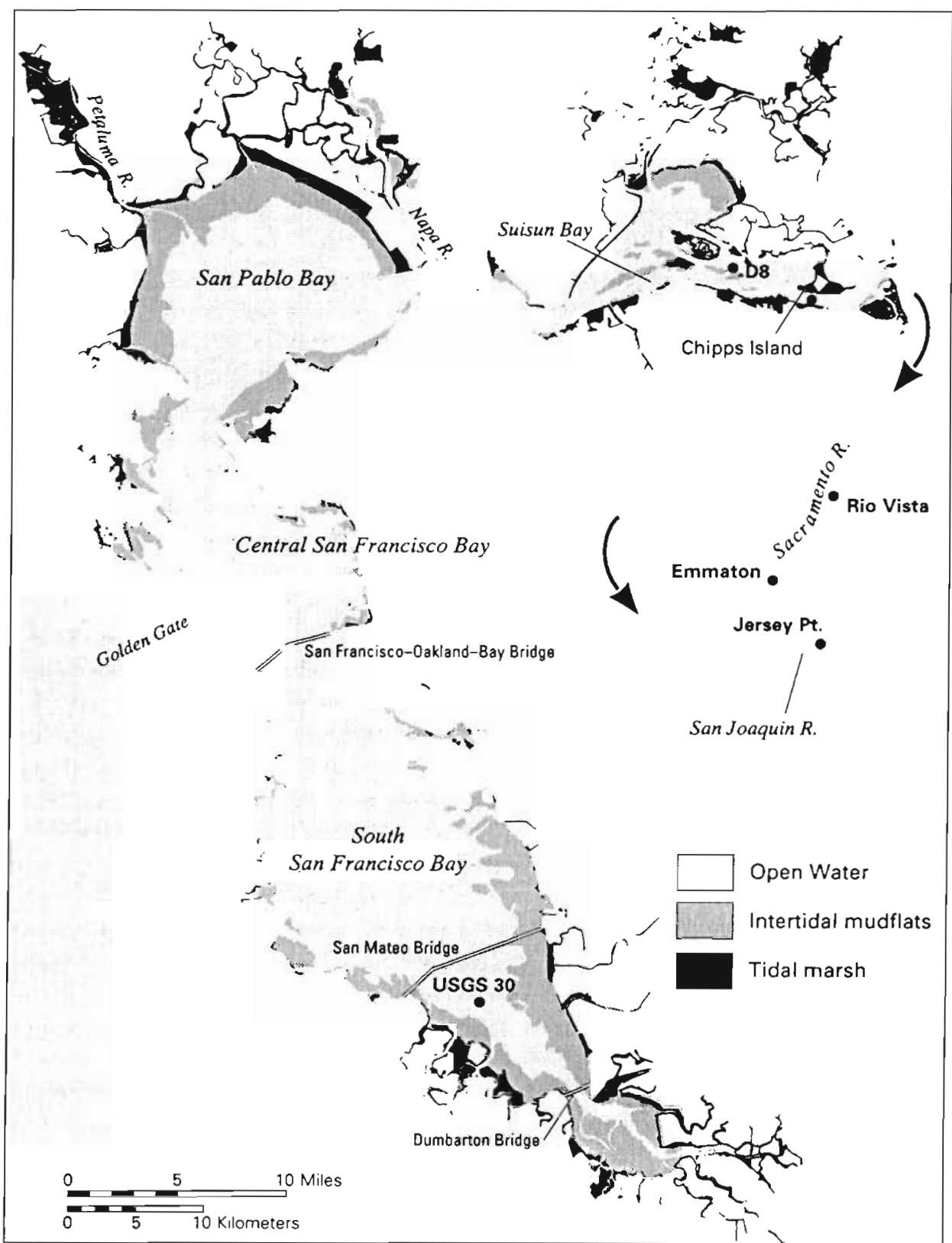

Fig. 1. San Francisco Bay, California, USA, showing the major subembayments and estuarine habitats. Inset shows portions of the Sacramento and San Joaquin rivers just upstream of Suisun Bay inflows: spatial distributions of salinity, suspended sediments, nutrients, plankton, and benthic communities all respond to seasonal and interannual fluctuations in discharge of the Sacramento-San Joaquin Rivers (Cloern \& Nichols 1985). We therefore ask how differently these 2 subembayments are organized on a systemic level, as described by organic carbon sources and sinks. The deep Central Bay, connecting the northern and southern reaches with the coastal ocean, is poorly studied and therefore cannot be included in this analysis.

The carbon budget is also a function of time, not a collection of static quantities. Here, we focus on how the annual carbon budget changes from year to year. Although seasonal change in carbon budgets has been a subject of active investigation (Jansson 1988), much less information is available on interannual change. Fluxes contributing to the budget must change from one year to the next, and their relative importance may change as well. Unfortunately, estimates for each flux in SFB are available for only one or a few years, often not overlapping. Nevertheless, many fluxes that appear to dominate the carbon budget were measured during 1980, a year of 'intermediate' river inflow. We use 1980 as a reference 
point and estimate a budget for that year; we then examine, insofar as the data permit, how this budget changes over time.

Although various mechanisms underly the spatial and temporal variability in organic carbon fluxes, river inflows are of particular interest. First, as intimated above, many of the known differences between the northern and southern reaches of SFB can be ascribed to different river inflows, and temporal variability on the scale of years to decades in certain estuarine properties has also been attributed to variable inflows (Cloern \& Nichols 1985). Changeable inflows are thus likely to have marked effects on net organic carbon fluxes and, consequently, estuarine metabolism. Second, management of river inflows is one of the major means by which humans can exert a direct influence on the estuary; the consequences of this management for organic carbon sources and the resulting supply of food to higher trophic levels is clearly of great practical import. Finally, and in a similar vein, river inflows mediate an important pathway by which climatic fluctuations affect estuarine features; understanding how these inflows affect organic carbon sources may permit some insight into the long-term consequences of climatic trends on estuarine metabolism. We therefore examine spatial and temporal differences in the organic carbon fluxes primarily with regard to Sacramento-San Joaquin River inflows.

San Francisco Bay is a complex estuarine system that is connected to the Pacific Ocean through a narrow deep trough (Golden Gate; Fig. 1), and it receives freshwater inflows primarily from the Sacramento and San Joaquin rivers, which have a combined drainage of $153000 \mathrm{~km}^{2}$ (Conomos et al. 1985). These rivers carry runoff produced during winter storms and during spring snowmelt, so riverine inputs are highly seasonal. Riverine inflows are regulated through the collection of runoff in a series of reservoirs on the tributaries; by the diversion of river flow from the estuary, mostly to support irrigated agriculture; and by release of fresh water from the reservoirs during the dry summer-autumn to repel salinity intrusion. Runoff from the smaller local tributaries constitutes only about $10 \%$ of the annual source of fresh water to San Francisco Bay (Conomos et al. 1985). The local basin of San Francisco Bay comprises a large metropolitan area (nearly 6 million people) that has expanded to the shoreline, thus eliminating most of the tidal marsh that formed the pristine margin of the open bay in the last century (Atwater et al. 1979). The bay itself includes large expanses of intertidal mudflats and subtidal shallow embayments. These are incised by a narrow channel that is typically 10 to $30 \mathrm{~m}$ deep, except in the central basin at the estuary mouth where channel depth reaches ca $100 \mathrm{~m}$.

\section{CALCULATION METHODS AND RESULTS}

\section{Morphometric considerations}

First, we compiled bathymetric data to define habitat areas and volumes for each subembayment. Data for all open water habitat deeper than mean lower low water (MLLW) were interpolated from nautical charts for the nodes of a $0.25 \mathrm{~km}$ grid covering the entire bay (Burau \& Cheng 1989). A hypsographic curve referenced to the MLLW tidal datum was constructed for each major subembayment using these data (Fig. 2; Central Bay is also shown for completeness).

Hypsographic data for areas above MLLW were taken from other sources. First, published values of mean tidal level (MTL) and mean higher high water (MHHW), referenced to the MLLW datum, were averaged for each subembayment (USCOE 1977). Next, the values for MLLW, and thus MTL and MHHW, were referenced to the National Geodetic Vertical Datum (NGVD), again averaged for each subembayment (USCOE 1984). The areas between MLLW and both MTL and MHHW were then determined from tidal stage-area graphs referenced to the NGVD (Morrison 1988) (Table 1).

The hypsographs of South and North bays strongly resemble one another (Fig. 2). Shoal areas, defined here as shallower than $2 \mathrm{~m}$ relative to MLLW, occupy a large fraction of each subembayment, $47 \%$ in the case
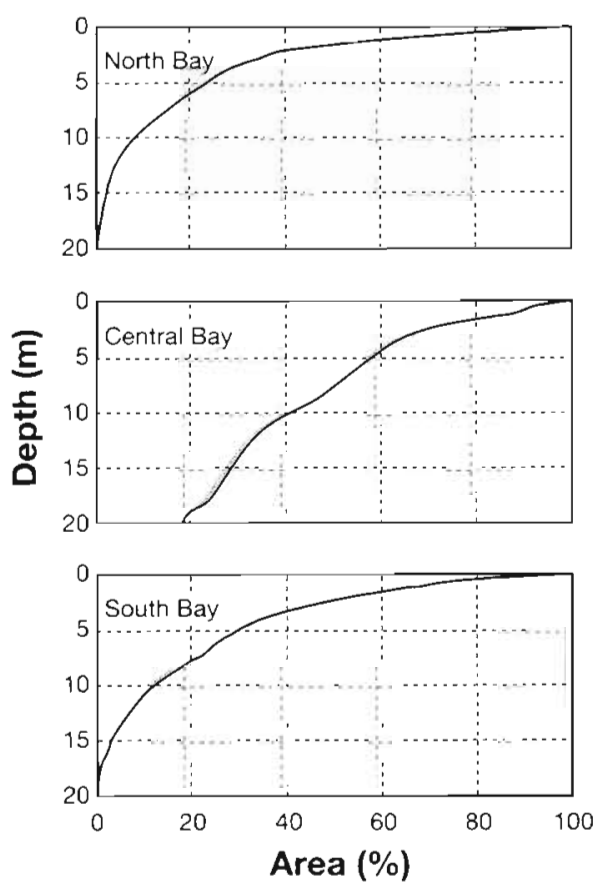

Fig. 2. Hypsographs for South, Central, and North San Francisco Bay down to a depth of $20 \mathrm{~m}$ 
Table 1. Morphometry of San Francisco Bay's major subembayments SB: South Bay; CB: Central Bay; NB: North Bay. Data for North Bay are

\begin{tabular}{|cccccccc|}
\hline Bay & \multicolumn{3}{c}{$\begin{array}{c}\text { Area } \\
\left(\times 10^{8} \mathrm{~m}^{2}\right)\end{array}$} & $\begin{array}{c}\text { Volume } \\
\left(\times 10^{9} \mathrm{~m}^{3}\right) \\
\text { MLLW }\end{array}$ & \multicolumn{3}{c|}{ Depth (m) } \\
\hline SB & 4.7 & 5.5 & 6.1 & 1.9 & 4.0 & 2.2 & 29 \\
CB & 2.2 & 2.4 & 2.5 & 2.5 & 11 & 7.7 & 99 \\
NB & & & & & & & \\
SP & 2.6 & 3.2 & 4.4 & 0.86 & 3.3 & 1.5 & 29 \\
SU & 1.0 & 1.2 & 1.7 & 0.31 & 3.1 & 1.8 & 28 \\
Total & 3.6 & 4.4 & 6.1 & 1.2 & 3.2 & 1.6 & 29 \\
\hline
\end{tabular}
further broken down into results for San Pablo Bay (SP) and Suisun Bay (SU)

stands are insignificant in both subembayments, as is rocky shore habitat for macroalgae. For the purposes of this carbon budget, vegetated tidal marsh was considered external to the system boundaries and an allochthonous source of organic carbon. The budget therefore refers to the entire area bounded by MHHW, exclusive of vegetated tidal marsh.

\section{Autochthonous sources}

Phytoplankton. Of the autochthonous organic carbon fluxes in the bay, phytoof South Bay and 60\% for North Bay (cf. median depths, Table 1). Maximum depths are also similar, a consequence of dredging activity to maintain shipping channels. In contrast, the Central Bay has a much smaller shoal area, occupying only $27 \%$ of the MLLW area, and a much deeper maximum depth.

Habitat areas within the estuary were determined by a variety of methods, as described in the following sections (Fig. 3). Note that phytoplankton shoal and channel habitat, benthic microalgal habitat, and vegetated tidal marsh are all significant in North Bay, while tidal marsh is relatively small in South Bay. Seagrass

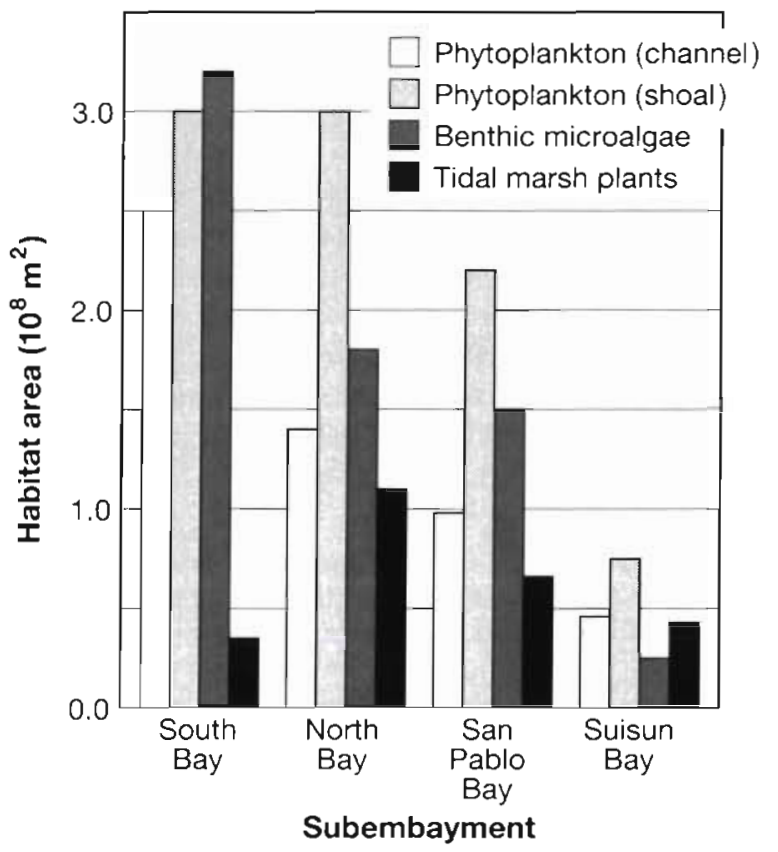

Fig. 3. Habitat areas for the main primary producers of South Bay and North Bay. North Bay can be further subdivided into San Pablo and Suisun bays. Seagrass habitat is too small to appear on this scale, and macroalgal habitat is probably insignificant as well. Habitat areas overlap and therefore do not sum to subembayment areas plankton productivity has been studied in the most detail. During 1980, productivity was determined monthly at 6 representative stations, including a shoal and channel site in each of South Bay, San Pablo Bay cubated in a deck box under natural light attenuated with neutral density filters (including a range of 1 to $100 \%$ of surface light). Estimates were based on ${ }^{14} \mathrm{C}$ uptake rates over $24 \mathrm{~h}$. Respiration rates in the dark were assumed to equal $10 \%$ of the maximum (lightsaturated) ${ }^{14} \mathrm{C}$ uptake determined from these $24 \mathrm{~h}$ incubations.

The results for these 6 stations can be converted to estuary-wide estimates of phytoplankton productivity. Because the depth of the euphotic zone - taken here as the depth at which irradiance declines to $1 \%$ of the surface value - varies continuously in time and space with changing turbidity, several simplifications were necessary (Fig. 4). First, the water level was assumed to be constant at MTL. Next, each subembayment was divided into a 'shallow' and 'deep' region at $2 \mathrm{~m}$ below

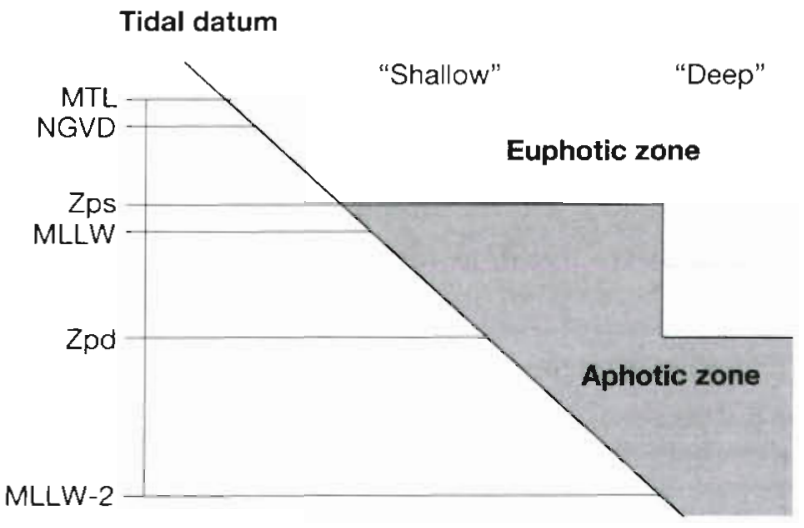

Fig. 4. Schematic cross-section of subembayment illustrating morphometric model used in the estimation of phytoplankton productivity. MLLW: mean lower low water; MTL: mean tidal level; NGVD: National Geodetic Vertical Datum; $z_{p d}$ : 'deep' photic depthi $z_{p s}$ : 'shallow' photic depth and Suisun Bay (Cloern et al. 1985). Samples were in- 
MLLW (ca $3 \mathrm{~m}$ below MTL), within each of which net photic zone productivity $\left(P_{\mathrm{np}}, \mathrm{g} \mathrm{C} \mathrm{m}^{-2} \mathrm{~d}^{-1}\right)$, biomass (b, mg chl a $\mathrm{m}^{-3}$ ), respiration rate below the photic zone $\left(r, g \mathrm{C} \mathrm{m}^{-3} \mathrm{~d}^{-1}\right)$, and photic depth $\left(z_{\mathrm{p}}, \mathrm{m}\right)$ were assumed to be constant at any given time. Then, $P_{n p}$ was integrated over area and year, resulting in estimates of net annual photic zone productivity $\left(\pi_{n p}, g \mathrm{C}\right.$ $\mathrm{yr}^{-1}$ ) for each region. Similarly, using the hypsographic data, the volume below the photic zone was determined for both shallow and deep regions. Phytoplankton respiratory losses were estimated for shallow and deep regions separately, integrated over the year, and subtracted from the corresponding values for $\pi_{n p}$, resulting in estimates for net annual

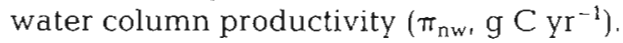

Because phytoplankton respiration rates for the aphotic zone are so uncertain, the phytoplankton productivity data are presented with and without respiration corrections (Table 2). Water column productivity, however, rather than photic zone productivity, represents the true supply of organic matter to consumer organisms. The data clearly demonstrate how aphotic respiration assumptions have a marked effect on water column production estimates, particularly in North Bay where aphotic losses account for a $29 \%$ average decrement in net photic zone production. On an areal basis, the productivity values in both South and San Pablo bays are similar, but they are substantially reduced in Suisun Bay and, hence, for North Bay as a whole. Shoal productivity is by far the major component in each subembayment. The shoal contribution of $110 \%$ for Suisun Bay reflects a negative channel productivity due to respiratory losses in the deep aphotic zone there. Respiration by autotrophs is therefore a signifi-

Table 2. Phytoplankton carbon productivity for South Bay (SB) and North Bay (NB) in 1980. Data for North Bay are further broken down into results for San Pablo Bay (SP) and Suisun Bay (SU). All numbers have been rounded to 2 significant digits. $\pi_{n p}$ : net photic zone productivity; $\pi_{n w}$ : net water column productivity

\begin{tabular}{|c|c|c|c|c|c|}
\hline Bay & $\begin{array}{c}\pi_{\mathrm{np}}^{\mathrm{d} \cdot \mathrm{b}} \\
\left(\mathrm{g} \mathrm{m}^{-2} \mathrm{yr}^{-1}\right)\end{array}$ & $\begin{array}{c}\pi_{n w^{a, c}} \\
\left(g^{-2} \mathrm{~m}^{-2} \mathrm{r}^{-1}\right)\end{array}$ & $\begin{array}{c}\pi_{n w} c^{c} \\
\left(\mathrm{Gg} \mathrm{yr}^{-1}\right)\end{array}$ & $\frac{\pi_{n p}-\pi_{n w}}{\pi_{n p}}$ & $\begin{array}{c}\text { Shoal } \pi_{n w}{ }^{d} \\
(\%)\end{array}$ \\
\hline SB & 150 & 130 & 76 & 13 & 62 \\
\hline NB & 130 & 90 & 45 & 29 & 78 \\
\hline SP & 140 & 100 & 39 & 25 & 74 \\
\hline $\mathrm{SU}$ & 87 & 44 & 5.6 & 50 & 110 \\
\hline \multicolumn{6}{|c|}{$\begin{array}{l}{ }^{a} \text { Based on area at MHHW corrected for tidal marsh habitat } \\
{ }^{b} \text { Assumes aphotic phytoplankton respiration is negligible } \\
{ }^{c} \text { Assumes a photic phytoplankton respiration is } 10 \% \text { of light-saturated } \\
{ }^{14} \mathrm{C} \text { uptake } \\
{ }^{d} \text { Percent of } \pi_{n w} \text { occurring in water shallower than } 2 \mathrm{~m} \text { referenced to } \\
\text { MLLW }\end{array}$} \\
\hline
\end{tabular}

cant component in the carbon budget of SFB that we have included implicitly in our estimates of net water column productivity. Similarly, Hopkinson (1988) calculated that autotrophic respiration consumes 13 to $68 \%$ of the gross primary production in 6 other coastal estuarine systems.

Benthic microalgae. The benthic microalgal community of SFB has been examined in several studies, most notably in terms of chlorophyll by Thompson et al. (1981) and in terms of species composition by Laws (1983, 1988). Productivity of this community, however, has never been measured in SFB, and we estimated the magnitude of this source based on habitat area and measurements reported for other systems.

Several researchers have tabulated results from benthic primary production studies (Riznyk et al. 1978, Colijn \& de Jonge 1984, Knox 1986). We combined these summaries with other recent studies (Thom 1984, Shaffer \& Onuf 1985, Varela \& Penas 1985, Fielding et al. 1988, Gould \& Gallagher 1990) in order to examine the distribution of productivity measurements. We used all locations where an annual production estimate was published, except for the 2 most northerly sites $\left(>57^{\circ} \mathrm{N}\right)$, which had extremely low values. Multiple estimates for other sites were replaced by their median value, resulting in a total of 28 site estimates. The overall median productivity was $110 \mathrm{~g} \mathrm{C} \mathrm{m}^{-2} \mathrm{yr}^{-1}$ and the first and third quartiles of the data set were 66 and $180 \mathrm{~g} \mathrm{C} \mathrm{m}^{-2} \mathrm{yr}^{-1}$, respectively. Because of the large uncertainty inherent in benthic productivity estimates, it would be premature to attribute the differences among studies to habitat or climatic differences (Shaffer \& Onuf 1985). We therefore used this median value as the estimate for average areal benthic primary production in the San Francisco estuary.

In order to maintain consistency with the simplifications introduced for estimating phytoplankton production, we defined the habitat for benthic microalgal production as all mudflat and open water areas extending down to a depth of $z_{\mathrm{p}}$ below MTL. The assumption is that, as for phytoplankton, benthic microalgae lying below the mean $1 \%$ surface light level do not receive sufficient insolation to grow. The upper boundary for the estimate of habitat area is MHHW, because the hypsographic information extends no further than this tidal datum. The entire area from MHHW to a depth of $z_{\mathrm{p}}$ below MTL was estimated for each subembayment, using the hypsographic curve for MLLW, the areas at MTL and MHHW, and the value of $z_{p}$ for each subembayment. As tidal marsh habitat is external to the boundaries under consid- 
eration, it was subtracted from this area. The resulting estimates of benthic microalgal primary production were $36 \times 10^{9} \mathrm{~g} \mathrm{C} \mathrm{yr}^{-1}$ in South Bay and $19 \times 10^{9} \mathrm{~g} \mathrm{C}$ $\mathrm{yr}^{-1}$ in North Bay.

Other autochthonous sources. Eelgrass Zostera marina appears to be the only seagrass of significance in the San Francisco estuary (Wyllie Echeverria \& Rutten 1989). Its distribution in the bay is limited, covering a total of only 128 ha. No productivity measurements have been made for these eelgrass stands, but temperate eelgrass communities, including those of the subtidal Pacific Coast, have productivities between ca 100 and $500 \mathrm{~g} \mathrm{C} \mathrm{m}^{-2} \mathrm{yr}^{-1}$ (Phillips 1974). In the absence of actual measurements, a value of $300 \mathrm{~g} \mathrm{C}$ $\mathrm{m}^{-2} \mathrm{yr}^{-1}$ was used here. Because the habitat area is so small, a more careful estimate of eelgrass production is unwarranted; regardless of areal productivity, this source of organic carbon is negligible.

Most macroalgae in the estuary are restricted to Central Bay (Silva 1979, Josselyn \& West 1985), but no attempt has been made to assess the total standing crop in any of the major subembayments. The patchy nature of macroalgal distribution reflects both the low availability of suitable locations for attachment and the mobility of drift communities floating along the estuary bottom. The scarcity of suitable locations, however, also limits total macroalgae coverage on an estuarywide basis, and their contribution to annual primary production is probably not significant (M. Josselyn pers. comm.).

The contribution of epiphytic algae has been included implicitly in estimates for other carbon sources.

We also considered the possibility that bacterial production of organic carbon, including both photo- and chemo-autotrophic processes, might be a significant source term. On the basis of habitat area and substrate concentration, we concluded that these sources must be negligible in SFB. For example, ca $2 \times 10^{9} \mathrm{~g} \mathrm{yr}^{-1} \mathrm{NH}_{3}-\mathrm{N}$ is contributed by the Sacramento-San Joaquin rivers (estimated from Peterson et al. 1985) and $3 \times 10^{9} \mathrm{~g} \mathrm{yr}^{-1}$ $\mathrm{NH}_{3}-\mathrm{N}$ from point source waste loads [estimated by combining $\mathrm{NH}_{3}$ : Biochemical Oxygen Demand (BOD) ratios from Peterson (1979) with BOD loads from CRWQCBSFBR (1987)]. If the entire amount were oxidized by nitrifying bacteria within the estuary, and assuming that $35 \mathrm{~mol}$ of $\mathrm{NH}_{3}$ are required for each mol of $\mathrm{CO}_{2}$ fixed (Atlas \& Bartha 1987), the corresponding organic carbon. production would be only $0.1 \times 10^{9} \mathrm{~g} \mathrm{C} \mathrm{yr}^{-1}$.

\section{Allochthonous sources}

Riverine loading. Based on biweekly flow-weighted measurements of dissolved organic carbon (DOC) at Rio Vista during 1980, Schemel (1984) estimated the
Sacramento River flow of DOC to be $150 \times 10^{9} \mathrm{~g} \mathrm{yr}^{-1}$ with a mean annual flow-weighted DOC concentration of $5.0 \mathrm{mg} \mathrm{l}^{-1}$. Particulate organic carbon (POC) was measured only from April through December, so an estimate of annual POC transport requires additional assumptions. As there was no apparent seasonal trend in the ratio POC:DOC, based on the 9 mo of overlapping data, the mean of this ratio, $0.10 \pm 0.02$ (SE), was used to estimate an annual POC load of $15 x$ $10^{9} \mathrm{~g} \mathrm{yr}^{-1}$. In the absence of adequate organic carbon measurements for the San Joaquin River and other smaller tributaries, the annual load of total organic carbon (TOC) into Suisun Bay was estimated by multiplying Sacramento River transport by the ratio of total riverine inflow to Sacramento River flow, a factor of 1.08 in 1980. Summing the estimates for DOC and POC, the 1980 TOC load into Suisun Bay was $180 \times$ $10^{9} \mathrm{~g} \mathrm{C} \mathrm{yr}^{-1}$.

Tidal marsh export. Because no direct measurements of marsh export to San Francisco Bay have been made, we must turn to results from other estuaries. We combined the tabulations of Nixon (1980) and Borey et al. (1983), including only those sites for which TOC or energy exports were available and converting energy to carbon on the basis of $9 \mathrm{~g} \mathrm{C} \mathrm{kcal}^{-1}$ (Borey et al. 1983). We also included studies by Howarth \& Teal (1980), Kjerfve \& McKellar (1982), and Roman \& Daiber (1989), resulting in a total of 10 sites. The overall median export was $150 \mathrm{~g} \mathrm{C} \mathrm{m}^{-2} \mathrm{yr}^{-1}$, which we adopt as a representative value for San Francisco Bay tidal marshes. The first and third quartiles of the data set were 100 and $410 \mathrm{~g} \mathrm{C} \mathrm{m}^{-2} \mathrm{yr}^{-1}$, respectively. Tidal marsh habitat areas for each subembayment were derived from NWI habitat maps for 1985 (Meiorin et al. 1991). Using the median value for marsh export rate, we estimate this source to contribute $5.2 \times 10^{9} \mathrm{~g} \mathrm{C} \mathrm{yr}^{-1}$ to South Bay and $16 \times 10^{9} \mathrm{~g} \mathrm{C} \mathrm{yr}^{-1}$ to North Bay.

Point sources. Organic carbon data are not part of the required monitoring program for point sources (primarily effluent from sewage treatment plants). As a result, we are compelled to make inferences about carbon loading from the routine measurements of BOD. The California Regional Water Quality Control Board-San Francisco Bay Region (CRWQCB-SFBR) has compiled municipal BOD loading to San Francisco Bay for the period 1955-1985, by subembayment (CRWQCB-SFBR 1987). Industrial discharge, not included in these loading estimates, accounted for only an additional $5 \%$ of BOD load, at least in 1985 (T. Wu pers. comm.).

The ratio of TOC to $\mathrm{BOD}$ is highly variable (Kim 1987), but we can arrive at a lower limit on theoretical grounds. A respiratory coefficient $\left(\mathrm{C}: \mathrm{O}_{2}\right.$ molar ratio) of 1 , typical of carbohydrates and proteins before nitrification of $\mathrm{NH}_{3}$, implies a TOC : BOD mass ratio of 0.38 . 
Dischargers usually report $\mathrm{BOD}_{5}$, which is typically two-thirds of the ultimate $\mathrm{BOD}$ in domestic sewage (Warren 1971). The corresponding $\mathrm{TOC}: \mathrm{BOD}_{5}$ ratio is thus 0.57 . This value would be reduced if some of the ammonia released were oxidized as well. The complete nitrification of $\mathrm{NH}_{3}$ to $\mathrm{NO}_{3}{ }^{-}$would result in a TOC: $\mathrm{BOD}_{5}$ of about 0.43 . As nitrification facilities, however, are not integrated into some of the larger treatment plants in the area, an intermediate TOC : $\mathrm{BOD}_{5}$ ratio is probably appropriate. Accordingly, we chose here a mass ratio of 0.5 ; a range of 0.5 to 1 is commonly encountered for municipal raw sewage and primary effluent (Meron 1970, Iskandar 1978), where one would expect the lowest values. Based on these assumptions and measured BOD loading for 1980 , we estimate point sources of organic carbon to be $6.6 \times 10^{9} \mathrm{~g} \mathrm{C} \mathrm{yr}^{-1}$ for the South Bay and $1.7 \times 10^{9}$ for the North Bay.

Runoff. The category of runoff is defined to be all loads to SFB carried by inflowing waters other than the combined Sacramento-San Joaquin River flow or point sources. The loading from runoff must be assessed through indirect methods, by combining typical TOC concentrations in runoff $\left(8 \mathrm{mg} \mathrm{l}^{-1}\right.$; Silverman et al. 1985, Smith 1989) with volumetric runoff estimates based on precipitation and land use (Gunther et al. 1987). We estimated urban runof $f$ to contribute $1.8 \times$ $10^{9} \mathrm{~g} \mathrm{C} \mathrm{yr}^{-1}$ to South Bay and $1.6 \times 10^{9}$ to North Bay in 1980 .

An upper limit on nonurban runoff can be estimated by multiplying non-Sacramento-San Joaquin stream flow into the bay (Meiorin et al. 1991) by the characteristic runoff concentration. The resultant loading from the 10 largest streams amounts to $1.8 \times 10^{9} \mathrm{~g} \mathrm{Cyr}^{-1}$ for South Bay and $2.6 \times 10^{9}$ for North Bay, approximately the same as urban runoff. These streams account for $64 \%$ of the area that drains directly into the bay, and so the estimates could be scaled upward somewhat. On the other hand, the streams also carry effluent from sewage treatment plants (Coyote Creek), tidal marsh export (Petaluma River), and some urban runoff, so the actual nonurban runoff may be far less.

Other allochthonous sources. We considered a variety of other possible allochthonous sources, but all were found to be negligible. Russell et al. (1982), for example, estimated an aerial fallout of $1.8 \times 10^{9} \mathrm{~g}$ $\mathrm{BOD}_{5} \mathrm{yr}^{-1}$ to the surface of $\mathrm{SFB}$ in 1978 , implying atmospheric deposition of only about $0.90 \times 10^{9} \mathrm{~g}$ TOC $\mathrm{yr}^{-1}$. On the basis of data for Chesapeake Bay, Gunther et al. (1987) extrapolated a total hydrocarbon deposition of only $0.045 \times 10^{9} \mathrm{~g} \mathrm{yr}^{-1}$ to San Francisco Bay. Oil spills are also common, although the mass loading from spills was estimated to be only about $0.09 \pm 0.01 \times 10^{9} \mathrm{~g} \mathrm{yr}^{-1}$ of petroleum hydrocarbons for 1984-1986 (Gunther et al. 1987) and presumably even less in terms of TOC. Russell et al. (1982) did not include groundwater among the significant freshwater sources to SFB. If groundwater flow is indeed a minor component of the water budget, then it is probably a negligible term in the organic carbon budget as well.

Exchange across the seaward boundaries is a potentially important source, but we could not assess its magnitude with existing data. The absence of information on exchange is a serious weakness with almost all organic matter balances in estuaries (cf. Wolff 1977; see below for more information).

\section{Carbon sinks}

Respiration. Hammond et al. (1985) measured benthic fluxes of total $\mathrm{CO}_{2}$ at a shoal and a channel station in South Bay. Three replicated measurements were made at each station from June 1980 through February 1981. We integrated these values over time and habitat area to estimate mean annual fluxes for shoal and channel regions. The fluxes were corrected for carbonate dissolution. The corrected fluxes $\left(62 \times 10^{9} \mathrm{~g} \mathrm{C} \mathrm{yr}^{-1}\right)$ were considered to represent the net effects of aerobic plus anaerobic respiration (presumably dominated by sulfate reduction and denitrification).

Additional respiratory losses must take place through planktonic bacteria and zooplankton metabolism. Although no water column measurements of respiration were made in 1980, a few measurements of light and dark $\mathrm{O}_{2}$ exchange were made in bay waters in 1976-1977 (Cole \& Herndon 1979) and again in 1984 (M. Pamatmat pers. comm.). We were unable to distinguish any significant differences among seasons, years, or subembayments, so we simply calculated the mean volumetric respiration rate for $24 \mathrm{hr}$ dark bottle incubations and applied it to both South and North bays. Carbon fluxes were determined by assuming a mean $\mathrm{C}: \mathrm{O}_{2}$ molar ratio of 1 (Hammond et al. 1985). Estimated water column respiration consumed $74 \times$ $10^{9} \mathrm{~g} \mathrm{C} \mathrm{yr}^{-1}$ in the South Bay and $46 \times 10^{9}$ in the North Bay.

Note that both benthic and water column respiration include contributions from microalgae, so respiratory losses due to heterotrophs are less than implied in the above estimates. As microalgal respiration has been included implicitly in estimates of benthic primary productivity and net photic zone productivity, as well as explicitly in net water column productivity, net system productivity cannot be determined simply by subtracting respiration from allochthonous sources.

Circulation and mixing. No attempt was made to estimate physical transport of organic matter by circulation and mixing across the seaward boundaries 
of the 2 reaches. Some of the available evidence indicates that this transport is a net sink, rather than a source. At the seaward boundaries, winter gradients of POC are negative seaward, and summer gradients are small, suggesting that mixing results in net losses from the 2 reaches (Conomos 1979b). Although seabed drifters move from outside the Golden Gate into Central Bay, especially in winter, further landward movement into either South or North Bay is limited (Conomos \& Peterson 1977). All the available evidence is circumstantial, however, and this term must be considered unknown in sign, as well as in magnitude. Estuarine circulation or dispersion could conceivably result in net upstream transport, particularly in the northern reach where freshwater inflows are so strong.

Dredging. Dredging and dredged material disposal result in the transport of large quantities of sediment within and between subembayments, and between Bay and ocean. Annual average Federal dredging has been tabulated for the period 1975-1985. Assuming a solids content of $34 \%$ (AHI, PWA 1990), a mean TOC : dry weight of $1.4 \%$ (Thomson-Becker \& Luoma 1985), and non-Federal dredging equal to $38 \%$ of the total (AHI \& PWA 1990), $7.4 \times 10^{9} \mathrm{~g} \mathrm{C} \mathrm{yr}^{-1}$ was transported from South Bay to the disposal site in Central Bay. In San Pablo and Suisun bays, dredging activity results only in a redistribution of organic carbon within the North Bay segment as defined here.

Permanent burial. Estimates of permanent burial are available only for South Bay. We used Hammond et al.'s (1985) estimate of the organic carbon burial rate, which was based on Fuller's (1982) budget for ${ }^{210} \mathrm{~Pb}$, yielding a net loss of $4.4 \times 10^{9} \mathrm{~g} \mathrm{C} \mathrm{yr}^{-1}$.

Active transport. Based on the fact that the major migrating fishes are at least 2 trophic levels higher than primary producers, we would expect them to remove an insignificant fraction of the organic carbon input. In San Francisco Bay, for example, the northern anchovy Engraulis mordax is the most abundant fish species. Adults and juveniles enter the bay in late spring and remain until autumn, feeding primarily on zooplankton. Migration back to the ocean removes an estimated $160 \mathrm{t}$ of new anchovy biomass annually (McGowan 1986), or ca $0.016 \times 10^{9} \mathrm{~g} \mathrm{C} \mathrm{yr}^{-1}$. The migratory biomass of piscivorous fish and marine mammals, and the consequent effect on TOC transport, is likely to be even less than for planktivore populations.

Harvest. Harvest losses are also probably negligible. The only commercial fisheries remaining in the bay are for northern anchovy and Pacific herring Clupeus harengus. Recent commercial catches of anchovy have stabilized at ca $380 \mathrm{t}$ (Smith \& Kato 1979) or only about $0.038 \times 10^{9} \mathrm{~g} \mathrm{C} \mathrm{yr}^{-1}$. San Francisco Bay attracts large spawning migrations of Pacific herring, with an estimated biomass of $71 \times 10^{9} \mathrm{~g}$ in 1989-1990 (J. Spratt pers. comm.). Up to $15 \%$ of the population can be harvested, which amounts to $1.1 \times 10^{9} \mathrm{~g} \mathrm{C} \mathrm{yr}^{-1}$. In both cases, most of the biomass comes from outside the bay, so the net loss from bay organic carbon pools is much smaller

Sport' fishing also must account for negligible amounts. The major species of recreational interest, striped bass Morone saxatilis and chinook salmon Oncorhynchus tshawytscha, are anadromous, and most of the harvested biomass is produced in the ocean. Migrating chinook salmon number between ca 70000 and 500000 , with a typical wet weight of $5 \mathrm{~kg}$. The equivalent organic carbon is only about $0.1 \times$ $10^{9} \mathrm{~g} \mathrm{C} \mathrm{yr}^{-1}$ (Gulland 1970), which would have a minor effect on the carbon budget even if it were all harvested from the estuary.

Summary of sources and sinks. Several groups of sources can be distinguished, based on their percentage contribution to the organic carbon supply of both subembayments (Table 3):

(1) The first group consists of those sources that were almost definitely unimportant. This group includes seagrasses, runoff, atmospheric deposition, and spills. These probably contributed less than $10 \%$ of the total in both subembayments.

(2) The second group consists of sources that also appear to be insignificant, but the evidence is anecdotal and the conclusion less certain. This group includes macroaigae, bacterial autotrophs, and groundwater.

(3) A third category consists of processes that contributed at least $5 \%$ in at least one subembayment. This group includes phytoplankton, benthic microalgae, river loads, tidal marsh export, and point sources.

Of the organic carbon sources, Groups 1 and 2 will be dropped from consideration in what follows. No evidence supports the notion that any of these processes are significant sources for the organic carbon pool, that they were notable in the past, or that they will be in the future (Russell et al. 1982, Silverman et al. 1985).

In South Bay, benthic and water column respiration dominated the organic carbon sinks for which estimates were possible (Table 4 ). Both dredging transport and permanent burial accounted for minor losses. Active transport and harvest were probably insignificant. In North Bay, benthic respiration and permanent burial could not be estimated from the existing data Of the remaining sinks, planktonic respiration was dominant, dredging transport was essentially zero, and both active transport and harvest were judged to be unimportant. 
parison among estuaries that, on a global scale, exhibit a wide range of influence by external sources. For example, phytoplankton primary production in the Fana Fjord (Norway) is $416 \mathrm{~g} \mathrm{C} \mathrm{m}^{-2} \mathrm{yr}^{-1}$ compared to areal averaged riverine inputs of $25 \mathrm{~g} \mathrm{C} \mathrm{m}^{-2} \mathrm{yr}^{-1}$ (Pearson 1988), so the ratio of autochthonous to allochthonous sources for this fjord-type estuary is 17 . In contrast, the ratio of autochthonous to allochthonous sources is only 0.07 in Grays Harbor estuary, Washington, USA (Thom 1984), where fluvial inputs of organic carbon overwhelm total autochthonous production. The contrasting carbon budgets for North and South SFB illustrate that these 2 subembayments fall near opposite ends of the global scale relating autochthonous and allochthonous sources of organic matter.

Such simple quantitative comparisons of source terms may provide little useful information, however, for comparing metabolism among estuaries because of the diverse qualitative nature of both autochthonous and allochthonous organic matter. A more useful index would be the ratio of utilizable autochthonous to utilizable allochthonous organic carbon, where the utilizable fraction is that component of $\mathrm{DOC}+\mathrm{POC}$ that can be biochemically oxidized faster than the hydraulic retention time of an estuary. For SFB, perhaps only about $10 \%$ of the river-derived organic carbon is utilizable. Based on measurements made by the California Department of Water Resources (DWR) from 1968-1977, the mean $\mathrm{BOD}_{5}$ along the Sacramento River between Rio Vista and Chipps Island was $1.3 \pm$ $0.1(\mathrm{SE}) \mathrm{mg} \mathrm{l}^{-1}$, which corresponds to $0.5 \mathrm{mg} \mathrm{l}^{-1}$ organic carbon (assuming respiratory quotient, $\mathrm{RQ}=1$ ). This measure of utilizable organic carbon is about $10 \%$ of the mean TOC concentration. Due to the organic matter contributions from the Sacramento-San Joaquin rivers, North Bay appears to have a much higher organic carbon supply than South Bay, 520 vs $210 \mathrm{~g} \mathrm{C}$ $\mathrm{m}^{-2} \mathrm{yr}^{-1}$. But if only $10 \%$ of the river contribution is utilizable, then North Bay sources amount to $200 \mathrm{~g} \mathrm{C}$ $\mathrm{m}^{-2} \mathrm{yr}^{-1}$, almost the same as South Bay. Freshwater inflow can thus be seen as inducing a tradeoff of indigenous microalgal production for inflows of external supplies of organic matter.

What is the nature of the utilizable fraction of fluvial organic carbon delivered to SFB? Based on measurements of chlorophyll and its degradation products, much of the POC appears to be river-borne phytoplankton and phytoplankton-derived detritus. Along with organic carbon, chlorophyll $a$ and phaeophytin a were measured in the lower Sacramento River at Rio Vista during 1980. The implied POC flux to North SFB

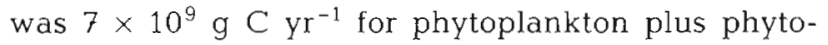
plankton-derived detritus (assuming a carbon: pigment ratio of 40 , and that phaeophytin a concentrations averaged $50 \%$ of chlorophyll a concentrations; Ball
1987). This represents about half of the estimated flux of utilizable TOC. Spiker \& Schemel (1979) found that the stable isotope composition of POC just upstream of Suisun Bay was characteristic of riverine phytoplankton, not of land plants. This result is consistent with the estimates presented here as well as observations that upstream phytoplankton blooms are often advected into Suisun Bay when flows exceed $300 \mathrm{~m}^{3} \mathrm{~s}^{-1}$ (Ball 1987).

These conclusions do not necessarily apply generally to other estuaries, because the nature and reactivity of fluvial organic matter is highly complex (Degens 1982) and dependent upon hydrologic and landscape setting of the river basin. For some river-estuary systems such as the Columbia River, northwestern USA (Small et al. 1990), perhaps Delaware Bay, Delaware, USA (Cifuentes et al. 1988), and North SFB, a substantial fraction of the utilizable allochthonous organic carbon appears to be derived from freshwater algae. However in other settings, such as the upper St. Lawrence estuary, Québec, Canada (Lucotte et al. 1991) or Dabob Bay, Washington, USA (Hedges et al. 1988), geochemical markers suggest that the bulk of the allochthonous POC is derived from terrestrial vegetation. A fundamental challenge for deriving useful indices for comparing estuarine metabolism is the development of a systematic approach for characterizing the chemical nature, origin, and reactivity of allochthonous organic matter that is delivered to estuaries from their watersheds. Development of such approaches is necessary before we can understand the ecological or biogeochemical significance of the differing origins of organic matter among estuaries, such as North and South SFB. For example, Smith et al. (1991) suggest that coastal ecosystems are generally 'net heterotrophic'; but what is the origin of the allochthonous organic carbon that supports system respiration at rates faster than in situ primary production? And are the pathways of metabolism different for different sources of organic matter? In this vein, Parsons et al. (1989) hypothesize a distinct 'heterotrophic food chain' based on riverine organic matter, and 'autotrophic food chain' based on phytoplankton production. If this hypothesis were true, then we could expect greatly differing food web dynamics and ecological efficiencies in the production of consumer organisms between North and South SFB, and other estuaries that have contrasting origins of organic matter.

\section{Organic carbon supply rates}

Although estuaries are generally perceived as highly productive ecosystems, there is a remarkable range in the areal rates of primary production among estuaries. 
Phytoplankton primary production varies about 2 orders of magnitude, from $<10$ to $>600 \mathrm{~g} \mathrm{C} \mathrm{m}^{-2} \mathrm{yr}^{-1}$ (Knox 1986). The mean $P_{\text {np }}$ for temperate-zone estuaries appears to be on the order of about $200 \mathrm{~g} \mathrm{C}$ $\mathrm{m}^{-2} \mathrm{yr}^{-1}$ (Boynton et al. 1982), so rates of phytoplankton primary production in $\mathrm{SFB}$ are relatively small: during $1980, P_{\mathrm{np}}$ was $150 \mathrm{~g} \mathrm{C} \mathrm{m}^{-2} \mathrm{yr}^{-1}$ for South Bay and 130 for North Bay. These values, however, are consistent with the concept of suppressed autotrophic production in estuarine systems having large riverine inputs of suspended sediments. Along the west coast of North America 2 other large river systems, the Columbia River and Fraser River estuaries, also have low phytoplankton primary production (55 and $120 \mathrm{~g} \mathrm{C}$ $\mathrm{m}^{-2} \mathrm{yr}^{-1}$, respectively; Small et al. 1990, Parsons et al. 1970).

The effects of turbidity are not limited to phytoplankton productivity. Seagrasses contribute significant amounts of organic matter in many estuarine systems and, because of their potential for much higher productivity than phytoplankton (Zieman \& Wetzel 1980), often raise mean estuary-wide productivity. In San Francisco Bay, eelgrass beds are limited to a mere $128 \mathrm{ha}$, and the main limitation on expansion of seagrass beds appears to be turbidity (Zimmerman et al. 1991). High suspended sediment concentrations therefore play a major role in the low total autotrophic organic carbon supplies for South and North SFB (190 and $130 \mathrm{~g} \mathrm{C} \mathrm{m}^{-2} \mathrm{yr}^{-1}$, respectively), which are less than the total primary productivity measured in the openwater habitats of other estuaries along the North American west coast: Tomales Bay, $330 \mathrm{~g} \mathrm{C} \mathrm{m}^{-2} \mathrm{yr}^{-1}$ (Smith et al. 1991); Grays Harbor estuary, $310 \mathrm{~g} \mathrm{C} \mathrm{m}^{-2}$ $\mathrm{yr}^{-1}$ (Thom 1984); Puget Sound, $465 \mathrm{~g} \mathrm{C} \mathrm{m}^{-2} \mathrm{yr}^{-1}$ (phytoplankton production only; Winter et al. 1975).

A further factor contributing to the low levels of combined organic matter sources in SFB is the small extent of tidal marsh habitat. When counted as an autochthonous source, the high productivity of tidal marsh vegetation relative to phytoplankton results in a higher estuary-wide areal productivity (2000 g C $\mathrm{m}^{-2} \mathrm{yr}^{-1}$ for Barataria Bay, Louisiana, USA; Hopkinson 1988). When counted as an allochthonous source, it acts as a supplement to autochthonous sources and will also increase the supply of total organic matter. The importance of marsh contributions abviously depends on the ratio of marsh to total estuarine habitat (Nixon 1980). This ratio has been drastically decreased in SFB by marsh leveeing and filling over the past $140 \mathrm{yr}$ (Atwater et al. 1979). According to the NWI wetlands inventory (Fig. 3), SFB tidal marsh in 1985 occupied only $144 \mathrm{~km}^{2}$, equivalent to ca $18 \%$ of the pre-1850 tidal marsh area. Assuming constant marsh export rates, tidal marsh would have contributed $117 \times 10^{9} \mathrm{~g} \mathrm{C}$ $\mathrm{yr}^{-1}$ to SFB if habitat area were the same as in 1850 .
The additional material $\left(96 \times 10^{9} \mathrm{~g} \mathrm{C} \mathrm{yr}^{-1}\right)$ represents an increase of $25 \%$ over 1980 loading. Tidal marsh contributions were clearly much higher in the last century, and the destruction of marsh habitat is a significant factor in the low organic matter supply to contemporary SFB. The elimination of marsh habitat upstream of the Bay may also have had a long-term effect on the quantity and quality of allochthonous materials carried in by the Sacramento-San Joaquin rivers.

A related issue is the long-term change in point source loading. BOD loads from municipal sources peaked in the 1960 s and then decreased at a remarkable rate, particularly since 1972 when the U.S. Federal Clean Water Act required a minimum of secondary treatment for all dischargers (CRWQCBSFBR 1987). BOD removal efficiency increased from $29 \%$ in 1955 to $95 \%$ in 1985 . The effect of the relatively rapid decrease in BOD loading on the organic carbon budget must have been substantial. In South Bay, for example, BOD loads decreased from 157 to $36 \times 10^{6} \mathrm{~g} \mathrm{~d}^{-1}$ between 1965 and 1980, a factor of 4.4 . The additional loading in 1965 was $22 \times 10^{9} \mathrm{~g} \mathrm{C} \mathrm{yr}^{-1}$, or $18 \%$ of total organic carbon sources in 1980 . North Bay experienced a 2.9-fold decrease in BOD loading between 1970 (the long-term peak year) and 1980. The contribution to total organic carbon sources was small, though, and the decrease probably did not change the budget substantially.

\section{River flow and interannual variability of organic carbon sources}

Each term of the annual carbon budget (Tables $3 \& 4$ ) represents the net sum of many complex processes that all vary in time. How much variability might we expect to see from year to year in the total supply of organic carbon to SFB, and where does the 1980 carbon budget fit within this expected range of interannual variability? Fundamental hydrological and ecological changes have occurred in SFB in recent years, including a 5 yr drought and sustained low river flow from 1987 to 1991; invasion of SFB by an exotic suspension-feeding clam (Potamocorbula amurensis) that has greatly altered seasonal phytoplankton cycles in the North Bay and caused a 5-fold decrease in primary production in Suisun Bay (Alpine \& Cloern 1992); and large declines in the abundance of virtually all species of fish that either reside in Suisun Bay or use this subembayment as nursery habitat (Herbold et al. 1992). To what extent are these changes related to interannual changes in the magnitude or character of organic matter that is available in SFB to support its food webs?

For South SFB, phytoplankton productivity is the only budget term that can be examined from the view- 
point of interannual variability; it does appear, however, to be the major source of organic carbon $(60 \%$ in 1980; Table 3). Cloern (1991) hypothesized a mechanism contributing to interannual variability in South Bay that acts through the influence of freshwater inflow on density stratification of the water column, which controls the balance between rates of phytoplankton population growth and consumption by the benthos. The long-term biomass record now suggests that this mechanism may be important only during years of extreme flows. The most complete chlorophyll series in South Bay (USGS Stn 30, Fig. 1) includes approximately 300 surface chlorophyll measurements from 1980 to 1991. The annual mean chlorophyll concentrations for this period were compared with mean Sacramento-San Joaquin River flow during February to May (covering the spring bloom period of maximum biomass and primary production). Although the Pearson correlation between chlorophyll concentration and river flow was significant $(r=0.78, p=0.026)$, the Spearman correlation was not $(\mathrm{r}=0.52, \mathrm{p}=0.084)$, reflecting the fact that a few extreme years (record floods of 1982-1983 and 1986) dominate the relationship. At lower flows, a wide range of chlorophyll concentrations is found. Regardless of the significance of the relation between phytoplankton biomass and river flow, the actual year-to-year variability in phytoplankton productivity is small in South Bay. Estimates of annual mean $P_{n p}$ had a coefficient of variation of $26 \%$ for the period $1980-1987$ ( $P_{n p}$ data from Cloern 1991). In contrast, annual Sacramento-San Joaquin River inflows during this period had a coefficient of variation of $81 \%$, with a maximum more than 13 times the minimum. We can only conclude that the response of annual organic carbon fluxes in South Bay to interannual river flow variability, insofar as we currently understand, is highly damped and perhaps only significant in years of extreme flow.

Unlike South Bay, riverine loading is a major source term for the North Bay and therefore a potentially important source of variability in its annual organic carbon budget. Data exist for an assessment of yearto-year fluctuations in the phytoplankton-associated carbon carried by river inflows, which may account for much of the TOC loading available for consumption. From DWR measurements, we determined the riverine loading of phytoplankton-derived pigments for 1975 to 1989 by summing flow-weighted chlorophyll $a$ and phaeophytin a concentrations from the Sacramento and San Joaquin rivers. Pigment loads were converted to organic carbon by assuming a carbon : pigment ratio of 40 . Although several long-term changes in upstream biomass and algal community composition have occurred since 1973 (Ball 1987), annual phytoplanktonderived loading during 1975 to 1989 appears to be largely proportional to annual river inflows, except in years of exceptionally high flows (Fig. 5). The drought period that began in 1987 was therefore a time of highly reduced loading from river inflows and probably of total allochthonous sources to North Bay. Note that this source of organic matter can vary by an order of magnitude among years.

Our understanding of variability in primary productivity in the North Bay rests largely on data for Suisun Bay, where long-term chlorophyll measurements have been sustained. Two main factors underlying interannual variability in biomass (chlorophyll a) have been implicated in Suisun Bay. The first is the effect of river inflow on residual circulations that retain phytoplankton biomass in the upper estuary (Ball \& Arthur 1979). The second is consumption by benthic herbivores (Nichols 1985), which is indirectly influenced by river inflows: during low flow periods of at least 16 consecutive months, estuarine benthic macroinvertebrates colonize Suisun Bay, leading to a large increase in their biomass and grazing impact (Nichols et al. 1990). As a result of these 2 processes, the interannual variability in $P_{\mathrm{np}}$ is much higher for Suisun Bay (and probably North Bay as a whole) than for South Bay. Estimates of annual mean $P_{\text {np }}$ from a channel station in Suisun Bay for 1974 to 1990 (Alpine \& Cloern 1992) have a coefficient of variation of $47 \%$, almost twice that of South Bay.

Together, phytoplankton production and riverine loading accounted for $85 \%$ of the organic carbon sources for North Bay in 1980 . Even if only $10 \%$ of the riverine loading were available, these 2 sources would account for $62 \%$ of the total. The figures are similar for Suisun Bay alone (Table 5). Variability in river flow therefore has a major impact on the total annual organic matter supply to the North Bay. Although we could not examine these impacts quantitatively for the entire northern reach, existing data do permit some

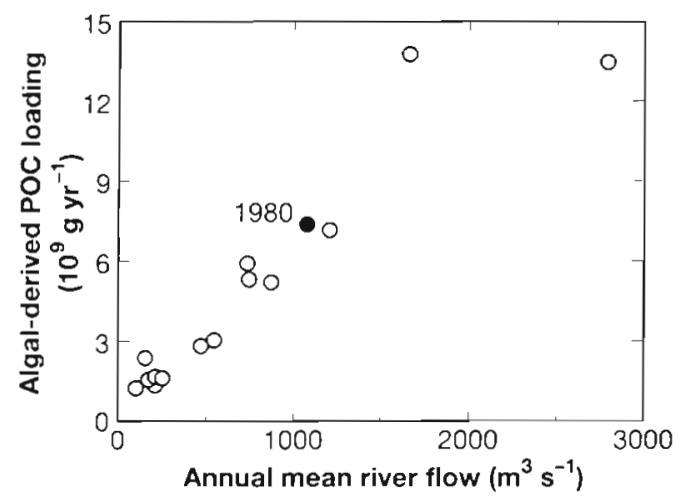

Fig. 5. Algal-derived organic carbon loading into North Bay, 1975 to 1989. Estimates are based on flow-weighted measurements of phytoplankton pigments at Emmaton on the Sacramento River and Jersey Point on the San Joaquin River (see Fig. 1) 
by heterotrophs respond to short-term changes in the supply of organic carbon (Hansen \& Blackburn 1992). Do processes of element cycling or rates of secondary production also vary from year to year in response to these interannual fluctuations in total organic carbon supply? How much of the year-to-year variability in the production by upper trophic level consumers is attributable to fluctuations in the annual supply of organic carbon to estuaries? Finally, can estuarine ecosystems exhibit year-to-year variability even in their net metabolism, shifting from net heterotrophy to net autotrophy, depending on annual fluctuations in rates of primary production and allochthonous loading? At this stage of estuarine science we know little about the system responses to interannual variability of organic carbon supplies of the magnitude demonstrated here for San Francisco Bay.

\section{SUMMARY}

Construction of an annual carbon budget shows that the primary sources of organic carbon to San Francisco Bay are autotrophic production by microalgae (mostly phytoplankton) and fluvial inputs of organic carbon from the Sacramento-San Joaquin rivers, with smaller contributions from point sources and perhaps tidal marshes. The primary sinks for organic carbon in South SFB (apart from possible contributions by circulation and mixing) are pelagic and benthic respiration, which appear to be of comparable magnitude.

The origin of organic matter differs markedly between the 2 subembayments of San Francisco Bay. In the lagoon-like South Bay, autotrophic sources dominate $(92 \%$ of total). In the river-dominated North Bay, however, most $(68 \%)$ of the total organic carbon supply is delivered by the Sacramento-San Joaquin rivers. These contrasts among the subembayments of SFB provide a unique opportunity for comparative study in one system to explore the role of fluvial inputs of organic matter on estuarine metabolism and food web dynamics. Here, as elsewhere, there is great uncertainty about the origin, chemical nature, and reactivity of river-derived organic matter.

Total supplies of labile organic carbon to San Francisco Bay are relatively small: $210 \mathrm{~g} \mathrm{C} \mathrm{m}^{-2} \mathrm{yr}^{-1}$ for the South Bay and 200 for the North Bay. Autotrophic production is suppressed by high concentrations of suspended sediments that limit habitat for submerged vascular plants and restrict phytoplankton primary production to a shallow photic zone. In addition, total system autotrophy has likely been reduced in the past $140 \mathrm{yr}$ through massive diking and filling of tidal marshes, and organic matter from sewage has decreased dramatically in recent decades.
Annual fluctuations in the total organic carbon supply to North SFB are larger than annual fluctuations in the South Bay, suggesting that river-dominated estuaries may, in general, have large interannual variability in their carbon budgets (and therefore system metabolism). For North SFB, most of this interannual variability is attributable to annual fluctuations in river discharge, which overwhelm variability associated with human activities such as marsh reclamation.

Acknowledgements. The work was funded by the San Francisco Estuary Project, U.S. Environmental Protection Agency (USEPA-CE-009604-01-0), the California Department of Water Resources (DWR Agreement No. B57517), and the U.S. Geological Survey. Many people generously provided data and suggestions. We particularly thank Randy Brown, Bruce Herbold, Peter Moyle, and Tim Vendlinski for their advice and support

\section{LITERATURE CITED}

AHI, PWA (Aquatic Habitat Institute, Philip Williams \& Associates) (1990). Status and trends report on dredging and waterway modification in the San Francisco estuary. San Francisco Estuary Project, Oakland, CA

Alpine, A. E., Cloern, J. E. (1992). Trophic interactions and direct physical effects control phytoplankton biomass and production in an estuary. Limnol. Oceanogr. 37: 946-955

Atlas, R. M., Bartha, R. (1987). Microbial ecology. Benjamin/ Cummings Publishing, Menlo Park, CA

Atwater, B. F., Conard, S. G., Dowden, J. N., Hedel, C. W. MacDonald, R. L., Savage, W. (1979). History, landforms, and vegetation of the estuary's tidal marshes. In: Conomos, T J. (ed.) San Francisco Bay: the urbanized estuary. Am Ass. Adv. Sci. San Francisco, p. 347-385

Ball, M. D. (1987). Phytoplankton dynamics and plankton chlorophyll trends in the San Francisco Bay-Delta Estuary. U.S. Bureau of Reclamation Exhibit No. 103, California State Water Resources Control Board hearings. U.S. Bureau of Reclamation, Sacramento, CA

Ball, M. D., Arthur, J. F. (1979). Planktonic chlorophyll dynamics in the northern San Francisco Bay and Delta. In: Conomos, T. J. (ed.) San Francisco Bay: the urbanized estuary. Am. Ass. Adv. Sci, San Francisco, p. 265-286

Borey, R. B., Harcombe, P. A., Fisher, F. M. (1983). Water and organic carbon fluxes from an irregularly flooded brackish marsh on the upper Texas coast, U.S.A. Estuar. coast. shelf Sci. 16: 379

Boynton, W. R., Kemp, W. M., Keefe, C. W (1982). A comparative analysis of nutrients and other factors influencing estuarine phytoplankton production. In: Kennedy, V. S (ed.) Estuarine comparisons. Academic Press, New York, p. $69-90$

Burau, J, R., Cheng, R. T. (1989). A general method for generating bathymetric data for hydrodynamic computer models. Open-File Report 89-28, U.S. Geological Survey, Sacramento, CA

CRWQCB-SFBR (California Regional Water Quality Control Board - San Francisco Bay Region) (1987). Historic changes in municipal loadings to San Francisco Bay 1955-1985. California Regional Water Quality Control Board - San Francisco Bay Region, San Francisco 
Cifuentes, L. A., Sharp, J. H., Fogel, M. L. (1988). Stable carbon and nitrogen isotope biogeochemistry in the Delaware Estuary. Limnol. Oceanogr. 33: 1102-1115

Cloern, J. E. (1987). Turbidity as a control on phytoplankton biomass and productivity in estuaries. Continental Shelf Res. 7: 1367-1381

Cloern, J. E. (1991). Annual variations in river flow and primary production in the South San Francisco Bay Estuary (USA). In: Elliott, M., Ducrotoy, J.-P. (eds.) Estuaries and coasts: spatial and temporal intercomparisons. Estuarine and Coastal Sciences Association 19th Symposium. Olsen \& Olsen, Fredensborg, p. 91-96

Cloern, J. E., Nichols, F. H. (eds.) (1985). Temporal dynamics of an estuary: San Francisco Bay. Hydrobiologia 129: 1-237

Cloern, J. E., Cole, B. E., Wong, R. L. J., Alpine, A. E. (1985) Temporal dynamics of estuarine phytoplankton: a case study of San Francisco Bay. Hydrobiologia 129: 153-176

Cole, B. E., Herndon, R. E. (1979). Hydrographic properties and primary productivity of San Francisco Bay waters, March 1976-July 1977. Open File Report 79-983, U.S. Geological Survey, Menlo Park, CA.

Colijn, F, de Jonge, V. N. (1984). Primary production of microphytobenthos in the Ems-Dollard Estuary. Mar. Ecol. Prog. Ser. 14: 185-196

Conomos, T J. (ed.) (1979a). San Francisco Bay: the urbanized estuary. Am. Ass. Adv. Sci., San Francisco

Conomos, T J. (1979b). Properties and circulation of San Francisco Bay waters. In: Conomos, T J. (ed.) San Francisco Bay: the urbanized estuary. Am. Ass. Adv. Sci. San Francisco, p. 47-84

Conomos, T J., Peterson, D. H. (1977). Suspended particle transport and circulation in San Francisco Bay: an overview. In: Wiley, M. (ed.) Estuarine processes, Vol. 2. Academic Press, New York, p. 82-97

Conomos, T J., Smith, R. E., Gartner, J. W. (1985). Environmental setting of San Francisco Bay. Hydrobiologia 129: $1-12$

Degens, E. T (1982). Riverine carbon - an overview. In: Degens, E. T (ed.) Transport of carbon and minerals in major world rivers, Part 1. SCOPE/UNEP Sonderband Heft 52, Mitt. Geol.-Palaeontol. Inst. Univ. Hamburg, p. 1-10

Fielding, P. J., Damstra, K. St. J., Branch, G. M. (1988). Benthic diatom biomass, production and sediment chlorophyll in Langebaan Lagoon, South Africa. Estuar. coast. shelf Sci. 27: $413-426$

Fuller, C. C. (1982). The use of Pb-210, Th-234, and Cs-137 as tracers of sedimentary processes in San Francisco Bay, California. MS thesis, Univ. Southern California, Los Angeles

Gould, D. M., Gallagher, D. E. (1990). Field measurement of specific growth rate, biomass, and primary production of benthic diatoms of Savin Hill Cove, Boston. Limnol. Oceanogr. 35: 1757-1770

Gulland, J. H. (1970). Food chain studies and some problems in world fisheries. In: Steele, J. H. (ed.) Marine food chains. Univ. California Press, Berkeley, p. 296-315

Gunther, A. J., Davis, J. A., Phillips, D. J. H. (1987). An assessment of the loading of toxic contaminants to the San Francisco Bay-Delta. Aquatic Habitat Institute, Richmond, CA

Hammond, D. E., Fuller, C., Harmon, D., Hartman, B. Korosec, M., Miller, L. G., Rea, R., Warren, S., Berelson, W., Hager, S. W. (1985). Benthic fluxes in San Francisco Bay. Hydrobiologia 129: 69-90

Hansen, L. S., Blackburn, T. H. (1992). Effect of algal bloom deposition on sediment respiration and fluxes. Mar. Biol. 112: $147-152$
Hedges, J. I., Clark, W. A., Cowie, G. L. (1988). Fluxes and reactivities of organic matter in a coastal marine bay. Limnol. Oceanogr. 35: 1137-1152

Herbold, B.. Jassby, A. D., Moyle, P. B. (1992). Status and trends report on aquatic resources in the San Francisco estuary. San Francisco Estuary Project, U.S. Environmental Protection Agency, Oakland, CA.

Hopkinson. C. Jr (1988). Patterns of organic carbon exchange between coastal ecosystems. The mass balance approach in salt marsh ecosystems. In: Jansson, B. O. (ed.) Lecture notes on coastal and estuarine studies, Vol. 22, Coastaloffshore ecosystem interactions. Springer-Verlag, Berlin, p. $122-154$

Howarth, R. W., Teal, J. M. (1980). Energy flow in a salt marsh ecosystem: the role of reduced inorganic sulfur compounds. Am. Nat. 116: 862-872

Iskandar, I. K. (1978). The effect of wastewater reuse in cold regions on land treatment systems. J. envir. Qual. 7: $361-368$

Jansson, B. O (ed.) (1988). Lecture notes on coastal and estuarine studies, Vol. 22, Coastal-offshore ecosystem interactions. Springer-Verlag, Berlın

Josselyn, M. N., West, J. A. (1985). The distribution and temporal dynamics of the estuarine macroalgal community of San Francisco Bay. Hydrobiologia 129: 139-152

Kim, S.-J. (1987). Significance of BOD, COD and TOC correlations in bio-kinetic models of activated sludge process. Tongyeong Fish. Jr. Coll. 22: 41-48 (in Korean)

Kjerfve, B., McKellar, H. N. Jr (1982). Time series measurements of estuarine material fluxes. In: Kennedy, V. S. (ed.) Estuarine perspectives. Academic Press, New York, p. 341

Knox, G. A. (1986). Estuarine ecosystems: a systems approach, Vol. I and II. CRC Press, Boca Raton, FL

Laws, R. A. (1983). Quaternary diatom floras and Pleistocene paleogeography of San Francisco Bay. Ph.D. thesis, Univ. of California, Berkeley

Laws, R. A. (1988). Diatoms (Bacillariophyceae) from surface sediments in the San Francisco Bay Estuary. Proc. Calif Acad. Sci. 45: 133-254

Lucotte, M., Hillaire-Marcel, C., Louchouarn, P. (1991). Firstorder organuc carbon budget in the St. Lawrence lower estuary from ${ }^{13}$ carbon data. Estuar. coast. shelf Sci. 32: 297-312

Malone, T. C., Crocker, L. H., Pike, S. E., Wendler, B. W. (1988). Influences of river flow on the dynamics of phytoplankton production in a partially stratified estuary. Mar. Ecol. Prog. Ser. 48: 235-249

McGowan, M. F. (1986). Northern anchovy (Engraulis mordax) spawning in San Francisco Bay, California, 1978-1979, relative to hydrography and zooplankton prey of adults and larvae. Fish. Bull. U.S. 84: 879-894

Meiorin, E. C., Josselyn, M. N., Crawford, R., Calloway, J., Miller, K., Pratt, R., Richardson, T., Leidy, R. (1991). Status and trends report on wetlands and related habitats in the San Francisco Estuary. San Francisco Estuary Project, U.S. Environmental Protection Agency, Oakland, CA

Meron, A. (1970). Stabilization pond systems for water quality control. Ph.D. thesis, Univ of California, Berkeley

Morrison, J (1988). The morphometry of the San Francisco Bay estuary. Philip Williams \& Associates, San Francisco

Nichols, F. H. (1985). Increased benthic grazing: an alternative explanation for low phytoplankton biomass in Northern San Francisco Bay during the 1976-77 drought. Estuar. coast. shelf Sci. 21: $379-388$

Nichols, F. H., Thompson, J. K., Schemel, L. E. (1990). Remarkable invasion of San Francisco Bay (California, USA) by the Asian clam Potamocorbula amurensis. II. 
Displacement of a former community. Mar. Ecol. Prog. Ser. 66: $95-101$

Nixon, S. W. (1980). Between coastal marshes and coastal waters - a review of twenty years of speculation and research on the role of salt marshes in estuarine productivity and water chemistry. In: Hamilton, P., Macdonald, K. B. (eds.) Estuarine and wetland processes: with emphasis on modeling. Plenum Press, New York, p. 437-524

Parsons, T. R., LeBrasseur, R. J., Barraclough, W. E. (1970). Levels of production in the pelagic environment of the Strait of Georgia, British Columbia: a review. J. Fish. Res. Bd Can. 27: 1251-1264

Parsons, T. R., Webb, D. G., Rokeby, B. E., Lawrence, M., Hopky, G. E., Chiperzak, D. B. (1989). Autotrophic and heterotrophic production in the Mackenzie River/Beaufort Sea Estuary. Polar Biol. 9: 261-266

Pearson, $T H$. (1988). Energy flow through fjord systems. In: Jansson, B. O. (ed.) Lecture notes on coastal and estuarine studies, Vol. 22, Coastal-off fhore ecosystem interactions. Springer-Verlag, Berlin, p. 188-208

Peterson, D. H. (1979). Sources and sinks of biologically reactive oxygen, carbon, nitrogen, and silica in northern San Francisco Bay. In: Conomos, T. J. (ed.) San Francisco Bay: the urbanized estuary. Am. Ass. Adv. Sci., San Francisco, p. 175-193

Peterson, D. H., Smith, R. E., Hager, S. W., Harmon, D., Herndon, R. E., Schemel, L. E. (1985). Interannual variability in dissolved inorganic nutrients in Northern San Francisco Bay Estuary. Hydrobiologia 129: 37-58

Peterson, D. H., Hager, S. W., Schemel, L. E., Cayan, D. R. (1988). Riverine C, N, Si and P transport to the coastal ocean: an overview. In: Jansson, B. O. (ed.) Lecture notes on coastal and estuarine studies, Vol. 22, Coastal-offshore ecosystem interactions. Springer-Verlag, Berlin, p. 227-253

Phillips, R. C. (1974). Temperate grass plots. In: Odum, H. T., Copeland, B. J., McMahan, E. A. (eds.) Coastal ecological systems of the United States. Conservation Foundation, Washington, DC, p. 244

Riznyk, R. Z., Edens, J. I., Libby, R. C. (1978). Production of epibenthic diatoms in a southern California impounded estuary. J. Phycol. 14: 273-279

Roman, C. T., Daiber, F. C. (1989). Organic carbon flux through a Delaware Bay salt marsh: tidal exchange, particle size distribution, and storms. Mar. Ecol. Prog. Ser. 54 $149-156$

Russell, P. P., Bursztynsky, T. A., Jackson, L. A., Leong, E. Y. (1982). Water and waste inputs to San Francisco Estuary - an historical perspective. In: Kockelman, W. J., Conomos, T. J., Leviton, A. E. (eds.) San Francisco Bay: use and protection. Am. Ass. Adv. Sci., San Francisco, p. $127-136$

Schemel, L. E. (1984). Salinity, alkalinity, and dissolved and particulate organic carbon in the Sacramento River water at Rio Vista, California, and at other locations in the Sacramento-San Joaquin Delta, 1980. Water Resources Investigations Report 83-4059, U.S. Geological Survey, Sacramento, $\mathrm{CA}$

Shaffer, G. P., Onuf, C. P. (1985). Reducing the error in estimating annual production of benthic microflora: hourly to monthly rates, patchiness in space and time. Mar. Ecol. Prog. Ser. 26: 221-231

Silva, P. C. (1979). The benthic algal flora of central San Francisco Bay. In: Conomos, T. J. (ed.) San Francisco Bay: the urbanized estuary. Am. Ass. Adv. Sci., San Francisco, p. $287-345$
Silverman, G. S., Stenstrom, M. K., Fam, S. (1985). Evaluation of hydrocarbons in runoff to San Francisco Bay. Association of Bay Area Governments, Berkeley, CA

Small, L. F., McIntire, C. D., MacDonald, K. B., Lara-Lara, J. R., Frey, B. E., Amspoker, M. C., Winfield, T (1990). Primary production, plant and detrital biomass, and particle transport in the Columbia River Estuary. Prog. Oceanogr. 25: 175-210

Smith, D. (1989). Upper San Pablo Creek Watershed nonpoint source monitoring program: 1988-89 project report East Bay Municipal Utility District, Oakland, CA

Smith, S. E., Kato, S. (1979). The fisheries of San Francisco Bay: past, present and future. In: Conomos, T. J. (ed.) San Francisco Bay: the urbanized estuary. Am. Ass. Adv. Sci., San Francisco, p. 445-468

Smith, S. V., Hollibaugh, J. T., Dollar, S. J., Vink, S. (1991). Tomales Bay metabolism: C-N-P stoichiometry and ecosystem heterotrophy at the land-sea interface. Estuar. coast. shelf Sci. 33: 223-257

Spiker, E. C., Schemel, L. E. (1979). Distribution and stableisotope composition of carbon in San Francisco Bay. In Conomos, T. J. (ed.) San Francisco Bay: the urbanized estuary. Am. Assoc. Adv. Sci., San Francisco, p. 195-212

Thom, R. M. (1984). Primary production in Grays Harbor Estuary, Washington. Bull. S. Calif. Acad. Sci. 83: 99-105

Thompson, J. K., Nichols, F. H., Wienke, S, M. (1981). Distribution of benthic chlorophyll in San Francisco Bay, California, February 1980-February 1981. Open-File Report 81-1134, U.S. Geological Survey, Menlo Park, CA

Thomson-Becker, E. A., Luoma, S. N. (1985). Temporal fluctuations in grain size, organic materials and iron concentrations in intertidal surface sediment of San Francisco Bay. Hydrobiologia 129: 91-107

USCOE (U.S. Army Corps of Engineers) (1977). Dredge disposal study, San Francisco Bay and Estuary: main report. U.S. Army Corps of Engineers, San Francisco District, San Francisco

USCOE (U.S. Army Corps of Engineers) (1984). San Francisco Bay: tidal stage vs. frequency study. U.S. Army Corps of Engineers, San Francisco District, San Francisco

Varela, M., Penas, E. (1985). Primary production of benthic microalgae in an intertidal sand flat of the Rio de Arosa, NW Spain. Mar. Ecol. Prog. Ser. 25: 111-119

Warren, C. E. (1971). Biology of water pollution control. W.B. Saunders, Philadelphia

Winter, D. F., Banse, K., Anderson, G. C. (1975). The dynamics of phytoplankton blooms in Puget Sound, a fjord in the northwestern United States. Mar. Biol. 29: 139-176

Wolff, W. J. (1977). A benthic food budget for the Grevelingen estuary, The Netherlands, and a consideration of the mechanisms causing high benthic secondary production in estuaries. In: Coull, B. C. (ed.) Ecology of marine benthos. Univ. of South Carolina Press, Columbia, p. 267-280

Wyllie Echeverria, S., Rutten, P. J. (1989). Inventory of eelgrass (Zostera marna L.) in San Francisco/San Pablo Bay. Administrative Report SWR-89-05, National Marine Fisheries Service, Southwest Region, Terminal Island, CA

Zieman, J. C., Wetzel, R. G. (1980). Productivity in seagrasses: methods and rates. In: Phillips, D. C., McRoy, C. P. (eds.) Handbook of seagrass biology: an ecosystem perspective. Garland STPM, New York, p. 87-118

Zimmerman, R. C., Reguzzoni, J. L., Wyllie-Echeverria, A., Josselyn, M., Alberte, R. S. (1991). Assessment of environmental suitability for growth of Zostera marina L. (eelgrass) in San Francisco Bay. Aquat. Bot. 39: 353-366 